\title{
THE METEOROLOGICAL OBSERVATIONS IN COIMBRA AND THE PORTUGUESE PARTICIPATION IN WEATHER FORECASTING IN EUROPE
}

\author{
ANTÓNIO JOSÉ F. LEONARDO, DÉCIO R. MARTINS AND CARLOS FIOLHAIS \\ Department of Physics and Centre of Computational Physics \\ Faculty of Sciences and Technology of the University of Coimbra \\ 3004-516Coimbra, Portugal \\ ajleonardo@iol.pt
}

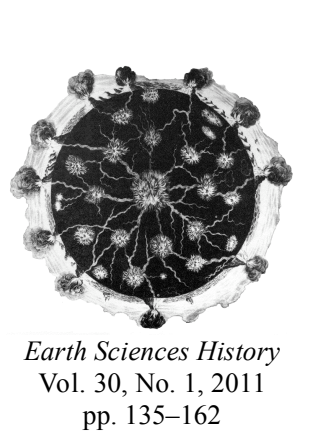

\begin{abstract}
In the early nineteenth century, regular meteorological observations started at the Faculty of Natural Philosophy of the University of Coimbra (FPUC). From 1854 to 1856 these observations were published in $O$ Instituto, a journal of an academic society of the same name, founded in Coimbra in 1852 . This new area of science aroused great interest, offering itself as unexplored territory waiting for scientific investigation. In reaction to the pioneering work at the Polytechnic School of Lisbon of Guilherme Pegado, who founded the first meteorological observatory in Portugal in 1854, the FPUC established a Meteorological and Magnetic Observatory in Coimbra. The main actor was, from 1863, the physicist Jacinto António de Sousa. In the twentieth century, the increasing need for weather forecasting, especially at sea, led to the creation of the Meteorological Services of the Navy in which Carvalho Brandão played a pivotal role. It was the beginning of an international cooperation that brought Jacob Bjerknes to Portugal. He addressed a conference at Coimbra recommending the creation of a meteorological station in the Azores, to relay observational data from vessels travelling in the Atlantic. The Portuguese meteorological services were scattered in various institutions until 1946, when the National Meteorological Services (NMS) were created. Based on articles published in $O$ Instituto and on the activities of the academy with the same name, we provide an overview of the evolution of meteorology in Portugal until the establishment of the NMS, with particular emphasis on the work of the Meteorological and Magnetic Observatory at the University of Coimbra.
\end{abstract}

\section{INTRODUCTION}

The study of the weather appeared as a new area of science with the invention of the first meteorological instruments, such as the thermometer and the barometer, in the seventeenth century, which allowed the systematic investigation of atmospheric phenomena (Middleton 1969). However, it was soon found that theoretical models to explain the weather and for making weather forecasts were difficult to obtain.

Throughout the nineteenth century, despite all the achievements in electromagnetism and thermodynamics, including the development of new physical concepts such as those of heat and energy, the field of meteorology was unable to achieve a mathematical approach that yielded worthwhile forecasts. The attempts to apply empirical methods to weather prediction, based on data gathered in meticulous and systematic observations had to compete with unscientific and popular methods, found in almanacs, whose reliability was in fact not very different from the scientific forecasts. This fact discouraged many researchers from engaging in this area, arguing that weather study was a "science of observation" (Anderson 2005, p. 7) that should be limited to a comprehensive collection of data, using accurate instruments, given that scientific speculation was difficult, if not impossible, to 
avoid. There was, nevertheless, the hope that, with sufficient information, gathered over long time periods and large areas, one could deduce and apply laws that explained the main weather events.

It was felt that progress in meteorology would have a decisive impact in many human activities such as maritime and aerial transport, hygiene and medicine, commerce, industry and agriculture. The weather manifestly had a direct "relationship with the greatest needs in life, and the most valuable interests of society and civilisation" (Carvalho 1871, p. 132).

Since Portugal had always been a country of sailors, concern with the weather was always present there. However, the search for scientific knowledge in this area only appeared in the nineteenth century, as in most European countries. That century saw the creation in Europe of meteorological services and institutes devoted to the study of atmospheric phenomena. Alphonse Quetelet (1795-1874) led meteorological observations at the Royal Observatory in Brussels from its foundation in 1831. By the order of the Spanish Government, meteorological observations were initiated at the Madrid Observatory in 1837. In Britain, the Meteorological and Magnetic Department of Greenwich was founded in 1840 , being followed by the Kew Observatory in 1842 (which was also concerned with meteorological observations), and the Meteorological Department of the Council for Trade, under the leadership of Robert FitzRoy (1805-1865), in 1854. The Meteorological Institute of Berlin was established in 1847, under the direction of Heinrich Dove (1803-1879). In Vienna the Central Institute for Meteorology, including a network of observers, was set up in 1848. In France, the meteorological services were divided between the Ministry of the Navy and the Paris Observatory, which in 1856 started a regular system of observations throughout the country, directed by Urbain LeVerrier (1811-1877). In the Netherlands, Christophorus Buys-Ballot (1817-1890) established the Central Meteorological Institute in 1854 , based in Utrecht and consisting of a network of thirty-seven stations. It was the first in Europe to issue storm warnings (Fleming 1998).

Global concern for establishing meteorological services increased with the sinking of warships of the British and French fleets, anchored in the Black Sea in 1854, during the Crimean war, due to extremely bad weather. If there had been a network of telegraphic communications connecting weather stations in many cities in Europe, the disaster could have been prevented, since the storm that hit the Black Sea had been observed in several European observatories a few days before the shipwreck (Cox 2002, pp. 85-90; Davies 1984, pp. 364-365).

Portugal was considered one of the most important locations for the establishment of meteorological stations and was connected, telegraphically, with other meteorological services in Europe so that advanced warning of storms coming from the Atlantic could be passed on to other European countries. However, this was not the only factor that promoted Portuguese meteorology: the effort and intervention of a charismatic person with international contacts, who could create the conditions for the establishment of a new scientific institution was required (Tavares 2009, p. 56), as was the case for many Portuguese achievements.

It is possible to distinguish two phases in Portuguese meteorology before the creation of the National Meteorological Service in 1946. The first occurred during the nineteenth century, its main purpose being to gather meteorological information, some of which was relayed abroad and therefore could be used to perform climatologic studies or, eventually, arrive at major laws pertaining to the atmosphere. This work was undertaken in the meteorological observatories of Lisbon and Coimbra.

Although a national network of observation sites was organised and storm warnings and daily local forecasts had been issued in Lisbon since 1865, a weather prediction bureau, based on scientific methods and synoptic meteorology, only appeared in the twentieth century. This second phase was also the product of the dedication of individual persons and 
justified by the international pressure to integrate Portugal into a multinational cooperation programme of weather monitoring and forecasting.

In the first phase, the leading figures were scholars from the University of Coimbra and the Polytechnic School of Lisbon, where the meteorological observations were also accompanied by geomagnetic and seismological observations.

\section{THE FIRST METEOROLOGICAL OBSERVATIONS IN PORTUGAL AND THE FOUNDATION OF THE PRINCE LUÍS METEOROLOGICAL OBSERVATORY}

There are references to meteorological observations in Portugal going back to the seventeenth century. According to Filipe Simões (1875), the Portuguese astronomer Antonio de Najera (or Naxera) ${ }^{1}$ compiled a set of meteorological observations in Lisbon in his book Summa astrológica, where one can read in the prologue:

If it is well received, and if the exposition of this matter pleases, I shall offer, God willing, to bring to light a compilation of meteorological observations and experiences related to the weather and air changes that I have been making at a certain time every day of the year, each of which was, in particular, warm, wet or dry, rainy, mild, serene, windy, stormy and, finally, accompanied by thunder and lightning, etc. ${ }^{2}$ (Simões 1875, p. 78).

The English physician Thomas Heberden (1703-1769) registered the weather in Madeira in 1747-1753 and submitted the outcome of his research to the Royal Society of London, having his results been published in the Philosophical Transactions (1752-1757). Extracts of meteorological observations, made in 1781-1785 by Jacob Pretorius Chrysostomo, a member of the Royal Academy of Sciences of Lisbon, were published in the Almanac of Lisbon in four volumes from 1782 to 1786 (Peixoto and Ferreira 1986, p. 262). José Bento Lopes (?-1800), a physician from Oporto, collected daily meteorological data in his city throughout 1792 (Monteiro 2001, p. 167).

However, some of the first meteorological observations in Portugal done in a systematic way and with a scientific purpose were only made, from 1816 on, by Marino Miguel Franzini (1779-1861), son of the Italian mathematician Miguel Franzini (? -1810), who had come to Portugal in 1772 at the invitation of the Marquis of Pombal, when the University of Coimbra (UC) was reformed; and he remained there until his death (Nunes 1988). Marino Franzini made a career in the Navy, having risen to the rank of Lieutenant of the Portuguese Royal Navy. Demonstrating an unusual interest in the weather, he set up a small observatory at his residence, where he collected daily data from 1816 to 1826 and again from 1835 to 1855 . In addition to knowledge of atmospheric data, Franzini wanted to characterise the climate of Lisbon and also to try to deduce the laws underlying the phenomena. A more practical goal was related to the assessment the annual rainfall in Lisbon and its distribution through the different seasons in order to improve public health and hygiene through the "water supply and underground sewage pipelines" (Nunes 1988). This first stage of meteorological observations had practical goals of both natural and medical character. The purpose was not to obtain scientific knowledge on meteorology per

\footnotetext{
According to his own account, he was a Lusitanian mathematician born in the city of Lisbon. There are, however, some doubts about his nationality since he was also mentioned as coming from Castile (Vasconcelos 1960).

$2 Y$ Y si fuera bien recebido, y agradar ela disposicion d'este asunto, me ofresco en breve com el favor de Dios salir a luz com una recopilacion de observaciones y experiencias meteorológicas ácerca de los tiempos e mudanças del Aire q tengo observado espacio de tiempo, todos los dias del ano, y cada uno en particular, los que fueron cálidos, los húmidos y secos, los lluviosos, los templados, y serenos, los ventosos, y tempestuosos, y finalmente en los que uvo truenos, relâmpagos, etc.
} 
se by deducing the laws governing the atmosphere and the weather, but to study its influence on human health.

In 1843, Guilherme José António Dias Pegado (1803-1885) asked the Government to establish a meteorological observatory in Lisbon, as part of the Polytechnic School. This institution would not only be "a subject of education but [also it would] create an uninterrupted sequence of [weather] observations as comparable and as comprehensive as possible, in the method and location most suitable for this purpose"3 (Ferreira 1940, p. 7).

Pegado graduated from the UC in mathematics and philosophy, finished a doctorate in mathematics in 1826, which led to his appointment as assistant in the Astronomical Observatory. But due to his liberal ideas he was forced into exile in Brest, France. After his return in 1834, he took up a chair in the Mathematics Faculty at Coimbra. He subsequently moved afterwards to the Polytechnic School of Lisbon, when this was established in 1837. The initiative for the foundation of a meteorological observatory annexed to the Polytechnic was related to the International Meteorological Conference held in Brussels on 23 August 1853. This meeting brought together representatives from the United States, Britain, Belgium, Denmark, France, The Netherlands, Norway, Russia, Sweden, and Portugal. The Portuguese representative was Joaquim de Matos Correia, a captain-lieutenant in the Royal Navy. The conference was organised by Quetelet and the Superintendent of the National Observatory in Washington, the American geographer Matthew Fontaine Maury (18061873), who had been compiling weather observations from American ships since 1842. In 1851, the British Government presented a proposition to the US Government to establish a uniform system of meteorological observations, both on sea and land. Maury's plans were more ambitious and it was he who proposed an International Conference on Meteorology. He sought to invite other nations to participate in this effort and reduce the perils of sea transportation and increase trading profitability by reducing the Atlantic passage times (Burton 1986, pp. 149-150). In Brussels, unanimous agreement was achieved on the form of a log to be used to record meteorological observations made by both merchant vessels and warships (Burton 1986, p. 151). The focus of the deliberations of the Conference was on maritime meteorology (Annaes do Observatório do Infante D. Luiz 1864, p. 6) because it was considered that the time was not yet ripe for trying to implement a similar system of observations on land.

The Prince Luís Meteorological Observatory of Lisbon began its operations in October 1854, and Pegado took office as observer and director. In a report, published with the first results of the work performed in 1856, Pegado addressed his indebtedness to Maury, Quetelet, Sabine and Welsh "whose guide, services and counselling were of great support" (Trabalhos do Observatório 1856, p. 1). His collaboration with the Paris Observatory started in 1857. Urbain Le Verrier had established a network of meteorological stations throughout France, linked by telegraph, which sent their observations to the Paris Observatory. A daily weather report, containing data from fourteen French stations and five foreign ones, was published in the journal La Patrie. These reports included the observational records from Lisbon. All meteorological data were compiled in a journal, later entitled Bulletin météreologique international, which was sent by LeVerrier to the directors of foreign observatories (Davis 1984, p. 365).

Storm warnings from the Prince Luís Observatory were issued, and alert signs were hoisted at the coastal stations. From 1853, all Portuguese warships were equipped with meteorological instruments and received instructions as to how to perform observations according to the system delineated at the Brussels Congress. Pegado superintended these

Um objecto de ensino mas para [nela] se formarem séries seguidas e ininterrompidas das observações [meteorológicas] comparáveis, e as mais completas possível, do modo e em local que fosse o mais próprio para este fim. 
operations and relayed to Maury the results taken aboard Portuguese ships. ${ }^{4}$ In a letter of 6 May 1857 Maury wrote to Pegado praising the Portuguese contribution (Raposo 2004, p. 549). But only in 1865 was a daily bulletin from the Lisbon's Observatory published in the Diário de Lisboa. It contained the weather predicted in the city for the following day.

Along with the meteorological observations, magnetic observations were also carried out, including data on declination and inclination. Portugal had joined the Magnetic International Union in 1857 and, in 1860, João Carlos de Brito Capelo (1831-1901), assistant to the Observatory and its future director, visited the Madrid, Paris and London observatories in order to acquaint himself with the methods of observation and view the magnetic equipment there available (Malaquias et al. 2005, p. 120).

\section{THE IC AND THE FOUNDATION OF THE MAGNETIC AND METEOROLOGICAL OBSERVATORY AT THE UC}

As a result of the initiative of a group of professors from the UC's Drama Academy, which was devoted solely to the performing arts, the Institute of Coimbra (IC) was founded in 1852 with the purpose of propagating studies in science, literature and fine arts (see Figure 1). The same year it started to publish $O$ Instituto, a literary and scientific journal containing memoirs written by IC members. The journal remained in publication, more or less continuously, for some 130 years, until 1981, with a total of 141 volumes being issued (Leonardo et al. 2009a). The activity of the IC allowed dissemination of the research done by UC professors, not only using its journal (which was exchanged with similar publications from other national and international institutions) but also to organise conferences and scientific visits.

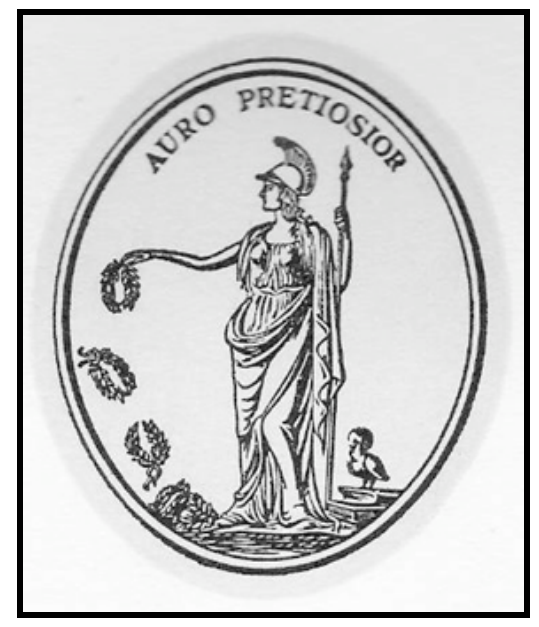

Figure 1.

The Institute of Coimbra insignia.

In January 1854, the meteorological observations made at the FPUC's Cabinet of Experimental Physics began to be published in $O$ Instituto. These observations were initiated in the early nineteenth century. In 1812, Constantino Botelho de Lacerda Lobo (1754-1820), Professor of Physics at the Philosophy Faculty of the UC, published meteorological observations in the Jornal de Coimbra from January 1812 to March 1817

4

The directorship of the Portuguese Nautical-Meteorological Services, charged with supervising and collecting meteorological observations from Portuguese vessels according to Maury's system, was assigned to Guilherme Pegado by the Portuguese Government in an ordinance dated 2 August 1853, a month before the Brussels conference (Ferreira 1940, p. 10). 
(Peixoto and Ferreira 1986, p. 263). Adriano Balbi (1782-1848), an Italian geographer and statistician who developed several lines of research in Portugal, published the observations of Lacerda Lobo from January 1816 to December 1820 in Statistical Essay of the Kingdom of Portugal and the Algarve, and described the equipment used (Santos 1995, pp. 11-14). However, these observations were of little scientific value since, besides not having been made at fixed hours, they were collected inside the Physics' Cabinet, not outdoors.

The monthly charts published in $O$ Instituto gave information on atmospheric temperatures and pressures (barometric height at $0^{\circ} \mathrm{C}$, the atmospheric vapour pressure, and the dry air pressure), the hygrometric study of the atmosphere (humidity and the mass of water vapour per cubic metre of air), and the direction of winds, all measured at noon. Maps of a few months also included the general state of the sky and the weather. Accompanying the last chart published on January 1856, there was a note by Matias de Carvalho e Vasconcelos (1832-1910), the acting Professor of Physics. It described the Cabinet of Physics as having "a good collection of instruments for the work of meteorological observations, and . . . an excellent anemometer with the latest improvements, and the first of this kind that appears among us",5 (Vasconcelos 1856, p. 119). In the same article, Matias de Carvalho recommended the establishment of a meteorological observatory in Coimbra, and that if the Faculty Council decided that a new building was impossible the facilities of the Astronomical Observatory should be used. The reasons were that the Faculty of Philosophy:

could not lag behind other natural science institutions or be less willing to promote studies that are now covered by the painstaking work of the most distinguished naturalists, and are cultivated with the utmost diligence in all the universities, to which meteorology owes the rapid and marked progress that has lately been achieved in other countries and even among us ${ }^{6}$ (Vasconcelos 1856, 119).

It was felt by the physics professors that other institutions, particularly the Polytechnic School of Lisbon, might overtake UC. As early as 1854, simultaneously with the beginning of the publication of meteorological observations, an article was published that criticised some of the data of Pegado's weather maps. The disagreement had to do with the values of atmospheric pressure, humidity and amount of water vapour per cubic meter (Goulão 1854a). This hints at a 'visibility attempt' on the part of Coimbra.

Several articles devoted to the weather appeared in $O$ Instituto at that period, some of which were authored by Antonio Sanches Goulão (1805-1857), Professor of Physics and Director of the Physics Laboratory. According to these articles, the weather depended on the distribution of heat over the Earth's surface so that, with the large number of facts available but with the paucity of known laws, this branch of physics still lagged behind the others (Goulão 1854b, p. 167). Goulão described the operation of liquid thermometers and the care required in their handling, using as an example the existing model at the Paris Observatory. A paper was also published on the 'system of winds', by the French navigator Jean Lartigue (1791-1876), in which a wind was defined as "a part of our atmosphere set in motion by a change in its equilibrium” (Lartigue 1854, p. 85). The article contained a description of the global winds.

Uma boa colecção de instrumentos para os trabalhos das observações meteorológicas, e entre estes um excelente anemómetro com os mais recentes aperfeiçoamentos, e o primeiro que neste género aparece entre nós.

6 Não podia ficar atrás dos outros estabelecimentos de ciências naturais, nem ser menos solícita em promover aqueles estudos, que são hoje objecto dos assíduos trabalhos dos mais distintos naturalistas, $e$ que em todas as universidades se cultivam com a maior diligência, e aos quais a meteorologia deve os rápidos e assinalados progressos, que ultimamente tem feito noutros países, e mesmo entre nós. 
In 1857, José Maria de Abreu (1818-1871), also professor at the FPUC and a member of IC, wrote an article that described work performed at the Meteorological Observatory of Madrid in 1854, when this was reorganised and equipped with new instruments. Based on the summary by Manuel Rico y Sinobas (1819-98), Professor of Physics and Director of the Madrid Observatory, Abreu described the equipment and work methods, emphasising the importance given by the Spanish Government to such activities. In fact, that Government ordered the printing of a summary of the Madrid observations and decreed that: "the observations made since 1855 in other universities and institutions of secondary education" (Abreu 1857, p. 174) should be added. Abreu concluded that it was necessary to establish weather stations in Oporto and Coimbra, like the Prince Luís Observatory in Lisbon, and to organise meteorological stations in all Portuguese secondary schools where physics and chemistry were taught, assembling all these results in an annual publication, similar to those in Spain.

The need for knowing the work undertaken in Europe in meteorology and other branches of the physical sciences led the University of Coimbra to send some of the members of its Faculty of Natural Philosophy on scientific missions abroad. Thus in 1857 Matias de Carvalho e Vasconcelos was in charge of a mission to France and other European countries, in order to appoint an engineer to be sent to Coimbra to oversee "the greenhouse construction and other projects planned in the botanical garden, the construction of the meteorological observatory, and further works on the various establishments of the Faculty" (Carvalho 1872, p. 145). In 30 March 1858, Matias de Carvalho sent his first report, published in $O$ Instituto, which described his visit to Greenwich Observatory in Britain and the Royal Observatory in Brussels. During his stay in Brussels, Alphonse Quetelet invited him to participate in the observations of the 15 March solar eclipse. During the period of this eclipse, meteorological observations were made every ten minutes, both inside and outside the observatory (Vasconcelos 1858).

On 1 March 1860, the Council of the Faculty of Natural Philosophy agreed to consult the Government about the construction of a meteorological and magnetic observatory (Carvalho 1872, p. 153). The letter began by stating the importance of meteorological and other geophysical studies then being pursued in many international institutions. It referred to the insufficiency of observations at a "single site of weather observation on the coast", a reference to the Lisbon Observatory. It restated the centrality of the UC: Coimbra was "indisputably the best suited location and where the foundation of a meteorological observatory could be made most economically"7 (Carvalho 1872, p. 154). Reference was made to the work of the FPUC's Physics Cabinet, the observations of which had been already published in $O$ Instituto, and the relations established by Matias de Carvalho with European observatories and international researchers, in particular Quetelet.

On 11 January 1861, the Faculty's Council appointed Jacinto António de Sousa (1818-1880) to assemble the material and technical resources for establishing a meteorological observatory and he was commissioned to coordinate the project of building the new observatory. Sousa was Professor of Physics and an authority in meteorology and terrestrial magnetism. One of his first initiatives was a visit to the Kew Observatory, in England, to collect magnetic instruments that had been ordered in London. The travel reports made by Sousa were published in $O$ Instituto in 1861 . The first, which took place between 6 June and 30 July 1860, included the observation of the 18 July solar eclipse at Cape Oropesa, Spain, and visits to various scientific institutions in Madrid, Paris, Brussels, London, Greenwich, and Kew. Since some of the institutions were closed or some of their professors absent, and due to the short duration of the visit, Sousa merely described the 
'physical spaces' and the collections of instruments. In Paris, with Matias de Carvalho as a cicerone, he met Le Verrier at the Paris Observatory. He then left for Brussels, where he met Quetelet, who showed him the astronomical meteorological and magnetic observatory. The final stage of the journey was London and the observatories of Greenwich and Kew, where he met George Biddell Airy (1801-1892), Edward Sabine (1788-1883) and Balfour Stewart (1828-1887). On 16 August, Sousa returned to the Kew Observatory, where he stayed for about two months and was helped in his work by the Director Balfour Stewart and his assistant Charles Chambers (1834-1896).

The first problem that should be solved was the location of the new observatory in Coimbra. Having concluded that there no building was already available, Sousa decided to build a new one. The first choice for location was the ancient castle, close to the university, where an astronomical observatory had begun to be constructed in the previous century, but given the proximity of a convent and the cost of demolishing walls this scheme was abandoned. The choice eventually fell on the site of Cumeada, outside the city centre. The conditions seemed suitable, although a doubt remained about the local geology, in particular the presence of red sandstone containing iron oxide, which might disturb the magnetic measurements. Samples of sandstone were then sent by diplomatic mail to General Sabine, who averred that the rock had no magnetic action (Sousa 1861, p. 115).

The concern about the site's magnetic activity shows that, from the very beginning, Sousa held that the new observatory should not be limited to meteorological observations, but should also serve for making magnetic observations. This situation was later confirmed by the focus in his reports on instruments at the Kew Observatory devoted to geomagnetism (Santos 1995, p. 91). He was also interested in solar observations and the influence of the Sun on the climate and Earth's magnetism. After visiting Kew, where he arrived on 26 August 1860, he referred in his report to the photoheliograph, probably the same as that used by Warren De la Rue (1815-1889), but owing to its cost and the prospect of further improvements in the field he gave up the idea of its immediate acquisition.

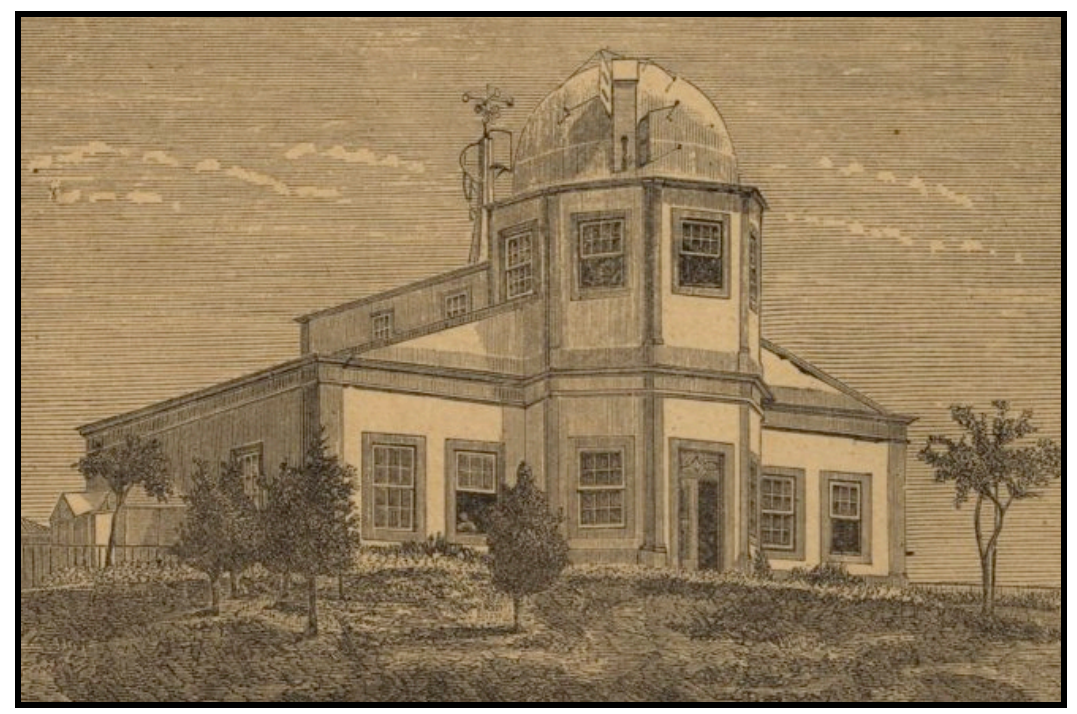

Figure 2. The OMM building (from the cover of Observações meteorológicas).

The building of the new observatory started in April 1863 (see Figure 2). On 1 February 1864 the meteorological observations began while the construction was still going on. From 6 a.m. to midnight the following data were monitored: atmospheric pressure, air temperature, water vapour and hygrometric state, the direction and approximate strength of 
winds, rainfall and evaporation, the maximum and minimum temperatures in the shade, in the grass and in the sun, and ozone measurements (Lopes 1893, p. 202).

\section{ACTIVITY OF THE METEOROLOGICAL AND MAGNETIC OBSERVATORY (MMO) OF THE UC}

Jacinto Sousa supervised the installation of the new instruments in the observatory and was its first Director. The first observations, from December 1864 to February 1865, were published in 1870 by the University Press under the title (in Portuguese) Summary of Meteorological Observations in the Meteorological and Magnetic Observatory, University of Coimbra (Sousa 1870).

In its preface, dated 31 March 1865, Sousa reported the observed meteorological parameters and the instruments used in its determination (Sousa 1870, pp. 3-7). Luke Howard's nomenclature, which established the types cirrus, cumulus, stratus and nimbus, was adopted to describe cloud formations, as well as a set of abbreviations to describe the general condition of the weather. Regarding the Observatory personnel, since many expressed interest in participating in the new work, Sousa volunteered to "instruct in practical observations whomsoever proved able to take advantage of an apprenticeship mutually free, with the objective of preparing many people, from whom, in due season, helpful employees would be brought"8 (Sousa 1870, p. 6). However, few continued this activity, and only one employee, João d'Almeida Araújo Pinto was in service in March 1865. All the work performed in the first year was due to the efforts of these two persons. Needless to say, there were at that time no automatic recording instruments.

While the development of work was conditioned by the shortage of technically adept but unpaid staff, António dos Santos Viegas (1837-1914), then occupying of the second chair of Physics, helped ensure the success of the project by taking part in the labour of the new observatory. It was his participation that made possible the organisation of the meteorological data into tables and graphs and then their publication. Sousa complained about this situation, saying that all the efforts were ineffective without proper and competent personnel, since the most important instruments remained inactive. This fact was preventing the regular collection of magnetic data and the making of meteorological observations. As early as 26 February 1864, the Faculty had informed the Government of the urgent need to appoint staff for the Observatory, but a year later there was still no response. The Observatory staff, including its Director, were only paid from August 1865 onwards.

After 1870 the staff consisted of the Director, three assistants and a guard; and the annual observations were published regularly. One of the assistants was responsible for the magnetic observations, which were initiated in July 1866 and consisted in determining the inclination, declination and horizontal absolute force. The two other assistants were in charge of the meteorological observations, leaving to the guard the photographic operations. Some instruments already had permanent automatic recording mechanisms such as the anemograph (recording anemometer) of Beckley and the baro-psychrograph (meteorograph). The observations made in Coimbra were distributed to many national and international observatories, as shown by the list included in the publication (Observações meteorológicas). ${ }^{9}$ A telegraphic communication with the Prince Luís Meteorological Observatory was also established by setting up a Breguet telegraph in 1867, which

8

Instruir na practica das observações quemquer que se mostrasse habilitado para tirar proveito d'um tirocínio reciprocamente gratuito, tendo em mira preparar muitas pessoas, d'entre as quaes, em tempo opportuno, sahissem empregados desde logo prestáveis.

The list of international institutions that received the publications from Coimbra's Observatory is very wide, including observatories and meteorological institutes from almost 40 countries all around the world. 
transmitted the daily observations ( 9 a.m.). Monthly summaries of the reports were relayed from the Lisbon Observatory to the Madrid and other observatories.

In 1878, the MMO received a silver medal at the International Exhibition of Paris, a as a result of the exhibition of some volumes of the Observatory's publications. The name of Jacinto de Sousa was engraved on the medal (Lopes 1995, p. 346).

After Sousa's death, Santos Viegas became Director on 23 August 1880. It was a natural choice given the commitment and interest that this professor had shown in the first years of operation of the observatory. Santos Viegas had graduated in Natural Philosophy in 1859 and had been appointed Professor of Physics at the Faculty of Natural Philosophy in 1870. In 1866 he visited some of the major European institutions to learn about the teaching of experimental physics. He held the position of Director of MMO until his death in 1914, being away only during the periods when he was Rector of UC. He was also President of the IC from 1885 to 1886.

Santos Viegas's leadership was soon felt. The Meteorological Congress in Vienna in 1873 issued a set of conventional signs and abbreviations to standardise the recording of meteorological phenomena. The new form of symbols was adopted in 1880 for the publication of magnetic and meteorological observations (Lopes 1995, p. 59). Another focus of Santos Viegas was the acquisition of new measurement instruments, not just those for registering meteorological phenomena but also for magnetic and seismic observations. In this area of geophysics, Santos Viegas, a member of the Società sismologica Italiana, was a national pioneer. In fact, the first seismological observations in Portugal were made in Coimbra. In 1903, a Milne horizontal pendulum was purchased and installed, the first observations on a voluntary basis being made by Egas Cardoso Fernandes e Castro who published a study of the earthquake of 23 April 1909 in O Instituto (Castro 1909). The inclusion of seismic results in the annual publication started in 1909, justifying the publication's title: Meteorological, Magnetic and Seismological Observations made in the Magnetic and Meteorological Observatory, University of Coimbra.

There are records of the acquisition by the Observatory of its first seismograph (an Angot B, No. 5388) in 1891, but there is no evidence that it was ever in operation, and its present whereabouts, if it is still in existence, are unknown. This purchase occurred during the period in which António Guedes Pereira Coutinho Garrido (1856-1895) served as interim director of MMO, and Santos Viegas was elected Rector of the University. The fact that it was an interim position, from 31 January 1890 to August 1892, and the precarious health of Coutinho Garrido may explain the fact that there was little investment in seismology at that period. Garrido sought only to maintain the work methods. However, despite the brevity of his life, he left an indelible mark in Coimbra, being one of its youngest professors (he graduated at the early age of nineteen and completed his doctorate at the age of twenty-two).

In the Paris Exhibition of 1889 another medal, this time a gold one, was awarded to the MMO, accompanied by a certificate of the French Republic. There is no mention to the achievements that led to the award, but it was probably related to the set of publications sent to Paris. The MMO was also invited to attend the Universal Exposition of 1900 (Lopes 1995, pp. 346-349). Santos Viegas was Rector of the UC once again, leaving his office of Director of the MMO from April 1906 to April 1907, and being replaced by Henrique Teixeira Bastos (1861-1943).

As a result of the death of Santos Viegas in 1914, Anselmo Ferraz de Carvalho (1878-1955) became Director of the MMO. Making use of the institution's vast collection of meteorological data, Carvalho published in 1922 a summary of the observations made in this city from 1866 on, which he called Climate of Coimbra (Carvalho 1922). In this work, the data collected over fifty years (1866 to 1916) were gathered together. The idea came after the submission in May 1916, to the Royal Meteorological Society of London (RSML), 
of the volumes of the Meteorological Observation of MMO. The response of the Secretary of the RSML was:

These are a very valuable contribution to our Library and give us very reliable information concerning the climate of Coimbra. I trust the observatory staff will, some day, find it possible to bring another volume of results combining all the observations from 1866 to 1915. This would give very valuable mean results for fifty years (Carvalho 1922, p. 5).

Another study based on Coimbra observations was carried out abroad. From scheduled barometric data collected between 1868 and 1929 and published in Meteorological Observations of the MMO of UC, the British mathematician Sydney Chapman (1888-1970) of the Imperial College in London and also a member of the IC, studied the atmospheric lunar tides at Coimbra ${ }^{10}$ (Chapman 1937).

\section{WEATHER FORECASTS AND THE FIRST METEOROLOGICAL SERVICES IN PORTUGAL}

Held in Vienna in 1873, the first International Meteorological Congress was chaired by the Dutch meteorologist Christophorus H. D. Buys-Ballot (1817-1890); and the International Meteorological Organisation (IMO) was founded at this meeting (Casati et al. 1998). Portugal was a founding member and was represented by Joaquim Henriques Fradesso da Silveira (1825-1875), by then the Director of the Prince Luís Observatory of the Lisbon Polytechnic. All Portuguese meteorological services were centralised in that Observatory, to which the daily observations made in the few meteorological stations spread across Portugal were channelled. The country's warships had adequate instruments and instructions for making meteorological observations, and their maps were sent to the Observatory of Lisbon (Ferreira 1940, p. 21). Although meteorological stations had been operating in the archipelagos of Madeira and the Azores since 1865, there was no telegraphic communication, so that the collected data took too long to reach the Continent and could not be used for weather forecasts. The need to correct this situation was pointed out by Buys-Ballot in a letter sent to the Portuguese Ministry of Navy in 1867 in which he presented a project to put a telegraphic cable between the observatory in the island of Corvo (in the Azores) and the Lisbon Observatory (Tavares 2009, p. 319). The Portuguese Government signed a first contract to construct a submarine cable in 1870 (Tavares 2009, p. 82) but, due to a breach of contract and political instability, the work was suspended for the next two decades.

Weather forecasting was still a controversial issue in the scientific community, as may be confirmed by all the criticism directed at Robert FitzRoy in the 1860s, when he was a pioneer in this activity, and also Le Verrier (Burton 1986, Davies 1984). ${ }^{11}$ A Portuguese proverb says that 'if you want to lie, start predicting the weather'. The secret of the local weather forecasts of Brito Capelo, of the Prince Luís Observatory in Lisbon, was his continued attention to the state of the sky, guided by his nautical 'sixth sense' (Branco 1935), like that of FitzRoy. Brito Capelo was the Portuguese representative at the second International Meteorological Congress, held in Rome in 1879 and he became a member of the International Meteorological Committee, an association established to act as an official organising body for the periods between congresses. Despite the rejection of Buys-Ballot's proposal to establishing an international fund for observation stations in islands or remote

The atmospheric tide is the height variation of the atmosphere due to the gravitational attraction of the moon or the sun, similar to what occurs in the seas and oceans. 
places in the globe, once again the need was expressed for Atlantic meteorological observations (Tavares 2009, p. 217).

Despite the rigour with which the meteorological observations were carried out, no one in Coimbra had ever tried to use them to predict the weather. This goal was desired by Santos Viegas, as can be inferred from the topic of the doctoral thesis he proposed to his student Bernardo Aires (?-1931): 'The Atmospheric Circulation and Weather Prediction'.

In his 1892 thesis, published by the Imprensa da Universidade, Aires analysed atmospheric phenomena based on the distribution of solar heat over the Earth's surface. Thus, taking due account of the Earth's rotation, the global winds, and those characteristic of the various regions of the globe, could be explained. The climate in Europe and the rest of the world was the result of combining the atmospheric movements of the air with the ocean currents. The second chapter of the thesis was devoted to atmospheric pressure and its variations, addressing the representation of maps with the distribution of pressures in a given region by isobars. He noted the advantage of using the pressure maps for predicting the air circulation and the recognition of low-pressure areas (cyclones), and areas of highpressure (anti-cyclones), and their distribution across the planet, forming the so-called action centres. Based on this theory, Aires explained some extreme weather conditions in Europe. In the next chapter he examined cyclones in more detail which he thought consisted of "considerable masses of air, animated of rapid rotating movement around a vertical axis, similar in many characters to eddies that form in the rivers"12 (Aires 1892, p. 49).

Regarding weather predictions, Aires started to address this topic considering that "if the theory of motions of the atmosphere were complete, one could determine the causes of their disorders and then their effects and the places where they are produced would be known"13 (Aires 1892, p. 69). The problem of the theories of that time was that they were unable to balance the effects of surface topography, the distribution of lands and seas, and other accidental causes. Aires addressed the application of the so-called 'laws of storms' based on the pressure gradients recorded to predict the weather in the short term. He stressed the relevance of telegraphic communications and described the national scene in his work.

Thus, in the late nineteenth century, as safeguard against Atlantic storms, Portugal only had a weather station in Funchal, Madeira, telegraphically connected to the Continent. The creation of similar stations in the Azores was dependent on the completion of a submarine telegraph cable, which only occurred in 1893 (Leonardo et al. 2009b). The Prince Luís Observatory worked as a monitoring centre, gathering at noon the observations made at 9 a.m. in the national meteorological stations of Lisbon, Portalegre, Oporto, Moncorvo Montalegre, Serra da Estrela, Régua, Coimbra, Évora, Vila Fernando, Lagos, Faro, São Vincente, and Funchal. It also received data from the Spanish posts of La Coruña, Barcelona, Madrid, Malaga, São Fernando, Tarifa and São Lourenço; and Valentia in Ireland. The daily charts of the weather were issued at one o'clock, and a daily report was published in the Diário do Governo (Aires 1892, p. 80).

Meteorological data from Oporto came from the Princess Amelia Meteorological Observatory, located at the Serra do Pilar in Oporto, the third meteorological observatory to be established in Portugal in 1888, which remained technically and administratively dependent on the Prince Luís Observatory until 30 August 1901 (Ferreira 1940, p. 7).

Regarding short-term local weather forecasting, Bernardo Aires included in his thesis methods based on joint measurements of the barometer, thermometer and hygrometer, reporting a set of rules to be applied according to these variations, such as: "if the barometer

Massas consideráveis de ar, animado de um movimento de rotação rápido em volta de um eixo proximamente vertical, semelhantes por muitos caracteres aos turbilhões que se formam nos rios. 
falls and at the same time the thermometer rises and the hygrometer indicates a higher degree of humidity, one can anticipate rain or snow, depending on the temperature or the state of agitation of the air"14 (Aires 1892, p. 86). Another possibility was the use of spectroscopy to detect the so-called 'rain bands', produced by the absorption of solar radiation by atmospheric water vapour and independent of the moisture content of ambient air, since they depended on the total thickness of the atmosphere traversed by the Sun's rays. The measurement of the scintillation intensity of stars, a phenomenon dependent on the weather, could indicate the possibility of weather change. Finally, the empirical predictions based on the shape and appearance of the clouds, the stars, and plant and animal behaviour were also addressed. Aires tried to make a comprehensive examination, utilising all the techniques then available, some more scientific than others, in an attempt to increase the probable success of any given prediction.

Aires ended his thesis analysing the possible effects of the lunar cycle, comets, or falling stars, showing that all the available data refuted their relevance to the weather, thus strengthening the value for long-term weather forecasting of the study of placement and displacement of action centres, particularly those that exerted their action on the European climate: the 'oceanic maximum', the 'Siberian maximum' and the 'oceanic minimum'. However, he did not continue his research on these subjects and played no role in the MMO during his career as a professor at the UC.

The early twentieth century saw a "sharp decline" (Peixoto 1986, p. 281) in the work performed at the meteorological observatories of Coimbra, Oporto and Lisbon, mainly due to internal disputes, lack of funding and a lack of technical staff with scientific training. Despite these circumstances, the first aerological studies, with the launching of probes attached to kites, started in Lisbon in 1907 (Ferreira 1940, p. 21).

In 1901, a national bureau of meteorological and geophysical observation was established in the Azores with the purpose of gathering information to be relayed by submarine cable to Lisbon and other European observatories. This initiative was due to the persistent efforts of Francisco Afonso Chaves (1857-1926) - a colonel of the Portuguese army and an expert in meteorology and geophysics - with the support of Prince Albert I of Monaco. As a result of British opposition and the Portuguese Government's fear of loss of sovereignty over the region, the internationalisation of this bureau was disallowed and it came under the jurisdiction of the Ministry responsible for education, comprising a network of four observatories (Tavares 2009).

Marine meteorology and weather prediction over the oceans attracted renewed attention. Admiral José Nunes da Mata (1849-1945), a professor at the Naval School, published Elementos de Meteorologia Náutica (Elements of Nautical Meteorology), which contained a chapter on weather prediction. He emphasised that it was not strictly prediction but the determination of atmospheric changes that were already occurring (Mata 1903, p. 254). That is, the method was based on phenomena that were already happening, but weather 'previsions' could be made on the basis of the winds and clouds, atmospheric pressure, temperature and hygrometric state of the air, the sea behaviour, or even by observations such as the aspect of the moon, atmospheric electricity, the colour of the sky and the bird behaviour, among others (Mata 1903, p. 258).

By a decree of 8 November 1921, a Technical Committee of Meteorology for the organisation of meteorological services was established, which included, among others, Ferraz de Carvalho and Carvalho Brandão. The committee provided an overview of the sorry state of the weather services, and stated that "the publication of the observations, 
either monthly or annually, has been made with great irregularity, mainly due to lack of resources"; there was a "lack of meteorological stations in many regions" and "oceanic weather, in which we should work with other maritime countries, has long been abandoned", so that the "meteorological services . . . [we]re fighting with many handicaps resulting from the lack of personal and material resources" (Projecto de organização 1936, p. 3). The committee recommended the creation of a Central Institute for Meteorology, with weather and climate offices.

\section{CARVALHO BRANDÃO AND SYNOPTIC METEOROLOGY IN PORTUGAL}

As described in the foregoing sections, the weather offices in Portugal did not provide a response to the requirements of the civil and military organisations. Although the meteorological observations were still carried out by several stations and observatories on the Continent and in Madeira and the Azores, there were no scientific studies in meteorology beyond the publication of the collected data.

In spite of the fact that the daily bulletin put out by the Prince Luís Observatory from 1882 onwards already included a map with isobaric lines (Ferreira 1940, p. 22), one can say that synoptic meteorology in Portugal only started in 1923, with the elaboration of meteorological maps covering Western Europe, and the application of new methods to weather forecasting based on their study. This work began after the creation of the Meteorological Services of the Navy (MSN) in 1922, an initiative of Vice-Admiral Eduardo Augusto Neuparth (1859-1925) and the meteorologist and naval officer António de Carvalho Brandão (1878-1937), the latter assuming the management of the services until 1928. Soon after the creation of the MSN, the General Marine Stewardship also requested the MMO to implement synoptic observations. These were to be sent from Coimbra to Lisbon in two daily bulletins (Santos 1995, p. 64).

Carvalho Brandão played a key role in meteorology in Portugal, particularly in weather prediction, and he represented Portugal at many international conferences, for example in London in 1921 and Utrecht in 1923. He also attended the joint congress of the Portuguese and Spanish Associations for the Advancement of Science, held in Coimbra in 1925 with the collaboration of the IC.

1925 was a year of great scientific activity in Coimbra. Francisco de Miranda Costa Lobo (1864-1945), then President of the IC and the Portuguese Association for the Advancement of Science, spurred on the creation of a section of astrophysics of the Astronomical Observatory of the UC. A new pavilion, where the spectroheliograph was installed, was built near the MMO (Leonardo et al. 2011). Ferraz de Carvalho was VicePresident of IC and Director of the Meteorological Magnetic and Seismological Observatory, which was renamed the Geophysical Institute (which name will be used hereinafter). At the Congress of Coimbra, Ferraz de Carvalho presented three communications on, respectively, meteorology, geology and seismology. ${ }^{15}$ In the communication on meteorology, he discussed the normal daily variation of atmospheric pressure in Coimbra. From 14 to 19 July the city received a large number of Portuguese and foreign scientists.

The memoir presented by Carvalho Brandão in the Coimbra Congress was entitled Modern Methods of Weather Forecasting in Portugal and started with an optimistic note on the state of meteorology, with the "formation of new hypotheses and the discovery of new laws and new methods for predicting the weather ..., characterised by intense scientific

15

The first was entitled 'The daily normal atmospheric pressure variation of Coimbra'. The second described 'The combined study by missions of Spain and Portugal of various geologic problems of the Peninsula' while the third pertained to the 'Close collaboration of the seismologic services of Portugal and Spain' (Trabalhos scientificos anunciados 1925, p. 626). 
activity, seeming at last to mark the actual beginning of a Meteorological Science, and thus the reasonable expectation of scientific weather forecasts, at least in the short term" 16 (Brandão 1925, p. 2).

Carvalho Brandão spoke on the use of synoptic charts showing isobars, thereby enhancing their value in representing weather conditions, but he estimated that they were insufficient for weather forecasts in the absence of any satisfactory scientific hypothesis to describe its changes. The main difficulties were in estimating the winds and forecasting rainfall, forcing the use of empirical methods or even the intuitions of experienced meteorologists in the predictions made. Four reasons were mentioned to explain the failure of the "classic treatise" by the English meteorologist Napier Shaw (1854-1945): the disposition of winds around the centres of low and high pressure depended on several factors that were thus far observed and recorded with little standardization; the impossibility of computing all the details of isobars and their irregularities, of great importance to the wind and the rain; the almost total ignorance of the state of the atmosphere at higher altitudes, and the inability to predict trends in the barometric field due to the lack of knowledge of the laws that governed it (Brandão 1925, pp. 4-5).

In the following pages, Carvalho Brandão described new methods developed during the First World War and in the post-War period. Based on German and Scandinavian research, with the special role of the Norwegians Vilhelm and Jacob Bjerknes (father and son), the 'theory of the polar front' had appeared. After working on the development of new theories in mechanics, Vilhelm Friman Koren Bjerknes (1862-1951) managed to apply them to the atmosphere successfully, through the recognition of the interactions of pressure and fields of movement, applying the laws of hydrodynamics, and allowing for the influence of frictional forces (Friedman 1989, p. 90). In 1917 Bjerknes founded the School of Meteorology of Bergen, where a group of young and dynamic researchers, among them his son Jacob Aall Bonnevie Bjerknes (1897-1975), devoted themselves to meteorological science, mainly to produce predictive models of the weather (Eliassen 1995, pp. 6-10). This school yielded a new model of cyclones, the origin of which was explained by the discontinuities between adjacent air masses at different temperatures. Using the terminology of the war, a cold air mass coming from a polar region and with a component to the west meets a mass of hot equatorial air with a component to the east, due to Earth's rotation, creating a 'polar front' - the region of contact between the two air masses. The relative motion of these air masses and the various energy transformations that followed determined the winds and weather events in the underlying surface. Through knowledge of the displacements of these lines of discontinuity (warm fronts, cold fronts or occlusions) it was possible to predict the weather in the corresponding locations.

During the First World War, French meteorologists had developed a new method based on the study of pressure-variation nuclei, obtained from the plot of curves of equal barometric variation at equal intervals, also referred to as isallobars. ${ }^{17}$ There was continuity in the movement of these cores of maximum variation, unlike the depressions in which the trajectory of a centre was sometimes irregular and capricious. From the forecast of the movement of these nuclei and their lines of variation, for twelve or twenty-four hours, new isobar lines for that extended time could be drawn and, on this basis, the winds and weather could be inferred. From France also came a new system of classification of clouds defining large groups, each of which had rules for their movement. The depiction of the cloud

A formação de novas hipóteses e a descoberta de novas leis e novos métodos para a previsão do tempo ... caracterizada por uma intensa actividade científica, parecendo marcar enfim de facto o início duma Ciência Meteorológica, e consequentemente a esperança fundada duma Previsão do Tempo científica, pelo menos a curto prazo. 
systems in synoptic charts, with their various features - central region of rain, front of bad weather approaching, uncertain weather margins and unstable weather tail—would be an additional tool in the process of prediction and one of the "most useful and secure" (Brandão 1925, p. 17).

The Italian method was based on the longstanding pressure variation with time, but transformed by the application of harmonic analysis and decomposition in different periods, according to the length of the forecast. According to Carvalho Brandão, despite the difficulties inherent in the damped wave character and the inability to predict the appearance of other factors, excellent results had been achieved in its application during the War.

Regarding the weather in Portugal, Carvalho Brandão justified the brief existence of the Navy's meteorological bureau and the inadequate information on the methods to be adopted. He emphasised, however, the need for close ties with Spain, and advocated a combined study of the meteorology of the Iberian Peninsula, because observations in both countries were essential to weather predictions on both sides of the border. He concluded that the Norwegian method could be used only in special circumstances, being more effective in the northerly countries, which also had greater coverage by the stations then operating in the North Atlantic. One solution would be the observations made on board ships that were to be sent by wireless telegraphy, provided that some constraints relating to accurate determinations of the locations of ships were made and problems of radiotelegraph traffic between ships and coastal stations were solved.

Overall, the French method was the most feasible and the depiction of isallobar lines did not offer great difficulty on the European continent and the British Isles (see Figure 3). Some communication problems with the posts in the Azores and Madeira were due to the delay in messages being sent by telegraph cable, since the communication via wireless telegraphy was not yet in operation. Carvalho Brandão said that the system of clouds was of little use in Portugal, a situation shared with other countries on the eastern shores of an ocean.

It is impossible to assert the impact of the Carvalho Brandão's communication with certainty. António Gião (1906-1969), one of the most renowned Portuguese meteorologists of the twentieth century, who was in 1925 studying at the UC, attended this conference and evidently made contact with Carvalho Brandão. In his autobiographical notes, Gião stated that it "was in the Congress . . . that I met an intellectual of a rare kind in Portugal. I'm talking of Carvalho Brandão. He was an enthusiast with a golden heart. It was he who brought freshness to the 'closed vase' of Portuguese meteorology". ${ }^{18}$

Aerological studies only started in the Geophysical Institute at Coimbra in 1926, after the acquisition of a recording theodolite of Hahn-Goerz, suitable for launching in balloons. For this goal, it was necessary to build an appropriate wooden tower for their launching (Santos 1985, p. 65). Initially, the balloons only recorded the direction and speed of the wind. But in 1929 three new instruments were acquired that allowed simultaneous measurements of pressure, temperature and humidity. Due to the need for greater lift, three balloons were used, which burst at high altitude. A smooth descent was provided by the use of a parachute "made in Coimbra, with a cloth from an umbrella" (Santos 1985, p. 78).

This sentence was taken from an undated manuscript of Gião, barely legible but transcribed by Stéphane Rouault in 2008, and entitled 'Autobiographical notes to clarify the reasons for my failure' (Gião, Notas autobiográficas). 


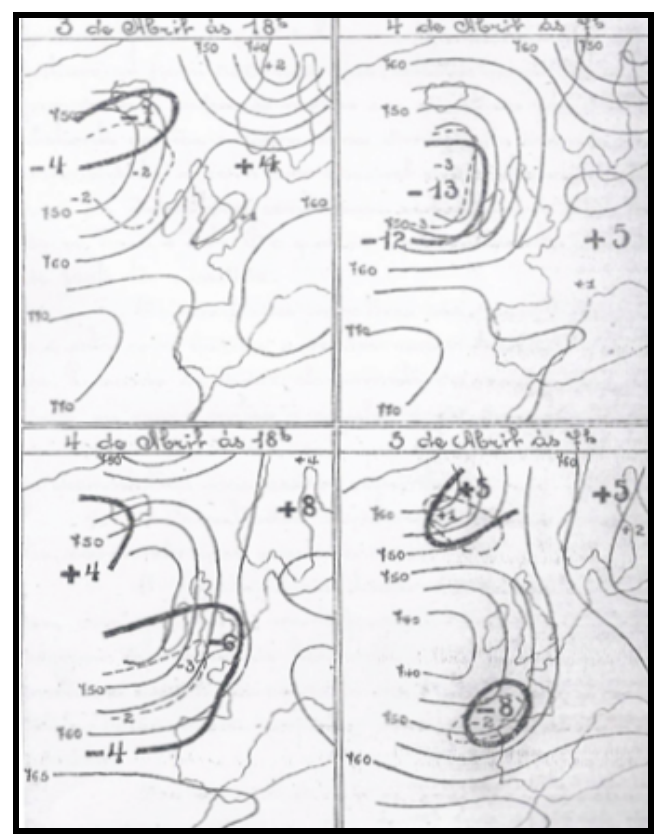

Figure 3.

Example of a prediction made by Carvalho Brandão in 1925. The thin lines indicate the isobars; the bold lines the $12 \mathrm{~h}$ nucleus of maximum variation; and the dashed lines the $3 h$ nucleus of maximum variation. From the first two maps it was possible to predict on 5 April "bad weather, strong wind from $\mathrm{SW}$ in the $N$ of the country and cool in the $S$ " (Brandão 1925, pp. 28 30).

\section{THE IMPORTANCE OF PORTUGAL FOR EUROPEAN WEATHER FORECASTING}

In late 1926, the IC decided to initiate a series of lectures on English culture, one of which was to be dedicated to the meteorology in Portugal, in relation to the meteorology in northwest Europe. Responsibility for the organisation of the meeting fell on Anselmo Ferraz de Carvalho.

On 8 May 1927, Jacob Bjerknes-according to the daily Diário de Notícias, a "renowned Norwegian meteorologist, author of modern theories applied to weather forecasting, who came to Portugal purposely to gather direct knowledge of meteorology in our country" (Diário de Notícias, 8 May 1927) - arrived in Lisbon. Another objective of Bjerknes' mission had been established at a meeting of meteorologists held in Zurich in 1926, where Carvalho Brandão announced the commitment of the Portuguese Government establish and run a wireless radio station in the Azores. A committee was therefore set up to monitor this matter until its final resolution, with General Émile Delcambre (1871-1951), Director of the French meteorological services, participating. He also came to Portugal and joined Carvalho Brandão and Bjerknes in a meeting with representatives of the Portuguese Government. Carvalho Brandão was at the time considered to be chief of the Portuguese meteorological services, despite the fact that a weather bureau was not yet consistently or coherently organised, being scattered in several institutions and observatories. In an interview on 13 May 1927 with Diário de Notícias held at a dinner at Carvalho Brandão's home, Bjerknes stated that a station in the Azores would solve "a problem that concerns the scientific bodies of Europe in charge of the study of weather prediction" due to the lack of observations from the North Atlantic, essential to the calculations. This project was "so important that if that station had been operating by then, France probably wouldn't have had to mourn the disappearance of Nungesser and Coli" - a reference to two French aviators who went missing that month while flying over the Atlantic (Diário de Notícias, 13 May 1927).

Given Bjerknes's presence in Portugal, he was invited by Ferraz de Carvalho to be the guest speaker at lecture held at the Instituto de Coimbra. So on 23 May he travelled from 
Lisbon to Coimbra, accompanied by the Norwegian Ambassador in Lisbon, Finn Koren, and Carvalho Brandão. After his lecture in the auditorium of the IC, Bjerknes returned to Madrid where he had a meeting with the Director of the Spanish meteorological services.

The communication of Bjerknes was published in $O$ Instituto and he was elected a corresponding member of the Coimbra society at the General Assembly of 2 June 1927. Entitled 'Les bases scientifiques et techniques de la prévision du temps et le rôle du Portugal à ce rapport' (Bjerknes 1928), Bjerknes began by recalling the importance of weather forecasts for maritime countries such as Norway and Portugal, despite the uncertainties of these estimates when compared with the astronomical predictions. Given the relationships of cause and effect in meteorology, Bjerknes presented a simplified classification of air currents and their relationship with weather. Clouds are formed by the cooling of air - a process that is more efficient when updrafts of moist air are occurring. The transport of air was chiefly based on two types of currents: the polar current, consisting of cold dry air, and the tropical current, containing warmer and wetter air. The meeting of two air masses at different temperatures gives rise to a surface of discontinuity that determines the weather. Based on the direction and speed of its propagation, it is possible to distinguish two cases: a cold front, where a moving wedge of cold air causes the ascent of a mass of warm air; and a warm front, which can be explained by a retreating cold air mass being pursued by a warm current that is bound to rise. In Bjerknes' description, the metaphorical use of a military term was unashamed, as if there were two armies in battle. He concluded that:

Le temps de demain dépend de la nature et de la force du courant d'air qui va arriver, éventuellement de la lutte entre deux ou plusieurs courants. Ce n'est q'un problème de distance et de vitesse de déterminer quel courant ou système de courants nous atteindra demain (Bjerknes 1927, p. 105).

Despite its apparent simplicity, the success of the forecast was dependent on the initial conditions, which required knowledge of the temperature, pressure, and humidity at each point in the atmosphere, from the Equator to the poles. To this goal, a system of stations relaying atmospheric data abroad by wireless telegraphy, scattered across the globe, was essential. At the time, four of these stations were in operation in Portugal: Porto, Coimbra, Lisbon and Faro, with two more, in Berlengas and Cape São Vicente, to be put into operation soon. Since new weather conditions generally move from west to east, the stations in western countries such as Iceland, Portugal and the United Kingdom were the leaders in Europe trying to predict storms approaching from the west coast, although their efforts were still insufficient. Solving the problem depended on the introduction of radio transmitters on transatlantic liners that would allow them to transmit meteorological data regularly during their crossing of the ocean. Other stations, strategically located to cover large geographical areas, would then relay the information to the European weather services, which collected all the transmissions (see Figure 4). Of course, Madeira and the Azores would be essential sites, and Bjerknes considered that the most important station would always be located in the Azores (Bjerknes 1928, p. 110).

At the Congress of Cadiz in 1927 Carvalho Brandão, as representative and head of the Portuguese Meteorological Bureau, presented a paper on 'Conditions for the advancement of Iberian meteorology' (Brandão 1927), which stated that the inauguration of the International Weather Station of Faial Island (in the Azores) was scheduled for the beginning of the following year, with the Portuguese Government already having achieved exemption of taxes for the companies that had the radio emission concession. The remaining problems were related to the insufficiency of reported observations from ships at sea and the excessive commercial radio traffic (Brandão 1927, pp. 11-13). Later called the Meteorological Station of the Atlantic, the Azores station became operational in 1929, a situation 
reported at the International Meteorological Congress held in Copenhagen that year (Morna 1934, 27). While in Copenhagen, General Delcambre received a telegram from Paris reporting that the Meteorological Station of Azores had managed to send a 'meteogram' with eighty-one groups of five digits each, related to the observations aboard steamships in the Atlantic. In the Congress's Synoptic Services Commission, Delcambre remarked on Portugal's significant contribution to science, which he classified as one of the most important events to the progress of meteorology in the last hundred years. It marked the beginning of a new era because the Azores station was the outcome of a large-scale international organisation, being a useful base for transatlantic navigation and aerial transportation (Saturnino 1934, pp. 20-21).

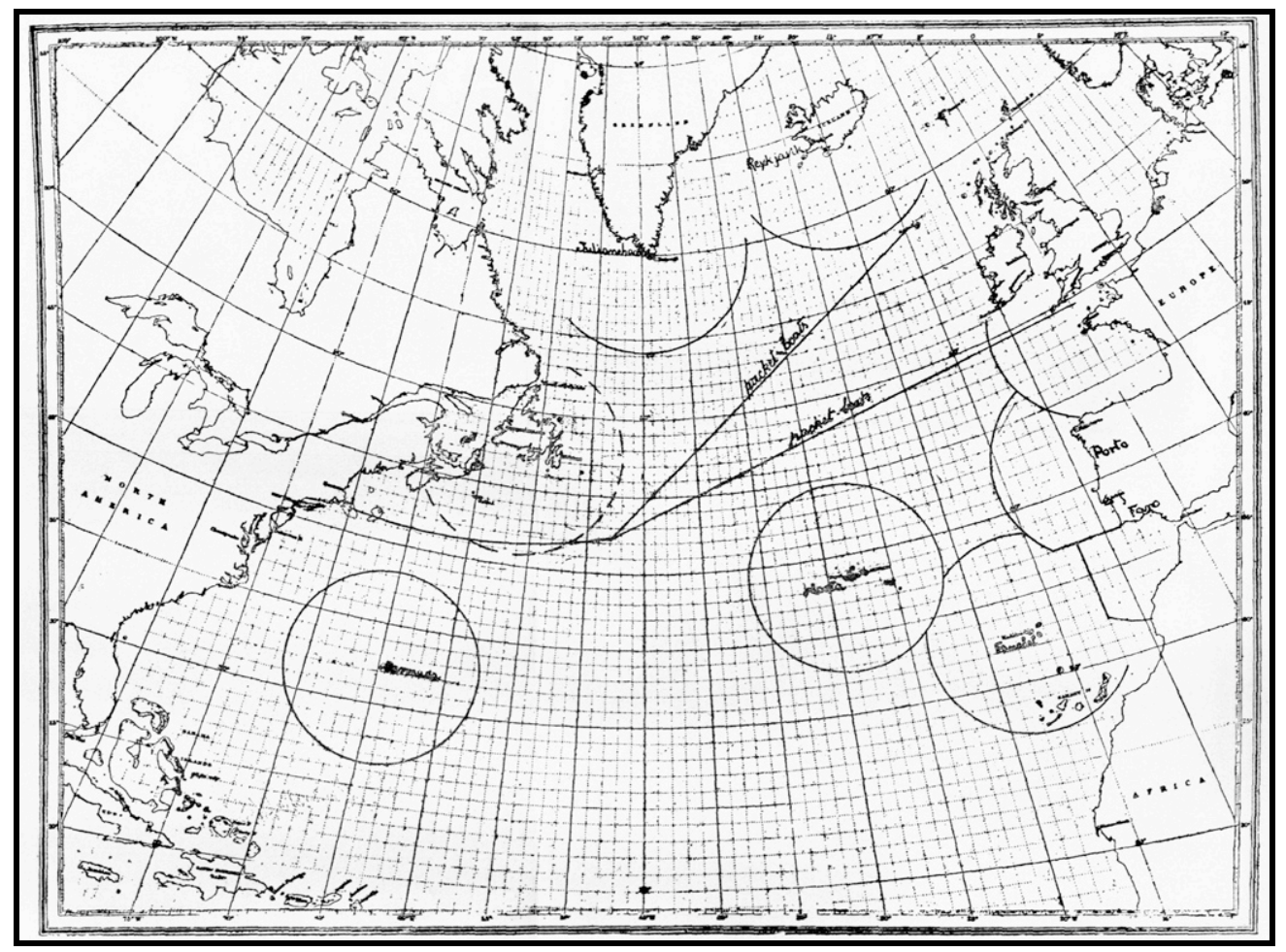

Figure 4. Location map of weather stations that received information from vessels within the areas of the circles (Bjerknes 1928).

At the meeting in Copenhagen in 1929, the major collective transmitters for the northern hemisphere were established, which were to incorporate and synthesise the information received from a wide range of international weather stations:

(a) from Western Europe and North Africa: Paris;

(b) from Central Europe: Hamburg;

(c) from European and Asiatic Russia: Moscow;

(d) transmission to North America of the 'meteos' from Europe and the Eastern Atlantic: London;

(e) transmission to Europe of the 'meteos' for America and the Western Atlantic: Arlington (Morna 1935, p. 19). 
The codes to use in transmissions and the daily schedules for ground stations and ships were also established in Copenhagen. Portugal actively participated in this global effort, the international station of Azores being considered a "key to the weather situation in Europe". In addition, the Azores was a "privileged place to collate the observations from ships" (Morna 1935, p. 23).

They are the vanguard of most of the disturbances, born of the confluence of the cold Labrador current, the warm Gulf Stream, or the intense low pressure centres in southern Newfoundland, passing north of the great Anticyclone of the Atlantic, along the polar front, which come to ravage Europe $^{19}$ (Morna 1935, p. 20).

From its creation and until 1946, the Navy's Meteorological Service maintained the task of weather forecasting in Portugal. According to Álvaro de Freitas Morna (18851961), successor to Carvalho Brandão as Director of the MSN, in 1934 this institution received observations from thirty stations and four national meteorological observatories. Among these, eighteen were international weather stations, which meant that the meteorological data were relayed overseas from Lisbon. Among the more than five million words that were, at the time, the annual turnover of the Navy's radiotelegraphic services, more than four million were related to the meteorological services (Morna 1935, p. 30)

A proof of the efficiency of the Atlantic weather prediction office was the meteorological preparation for the flight across the Atlantic of the airplane ESA (Espirito de Santo Agostinho), from Lisbon to New York, in 1931 (Morna 1932, p. 4). The flight crew, consisting of the pilots Costa Veiga, Christhien Johnson and Willy Rody, requested the cooperation of the naval Meteorological Service to determine the best route according to the weather forecast. In the event, this endeavour was unsuccessful, terminating in a sea landing due to lack of fuel (see Figure 5). However, the meteorological work was instrumental in the rescue of the pilots. ${ }^{20}$

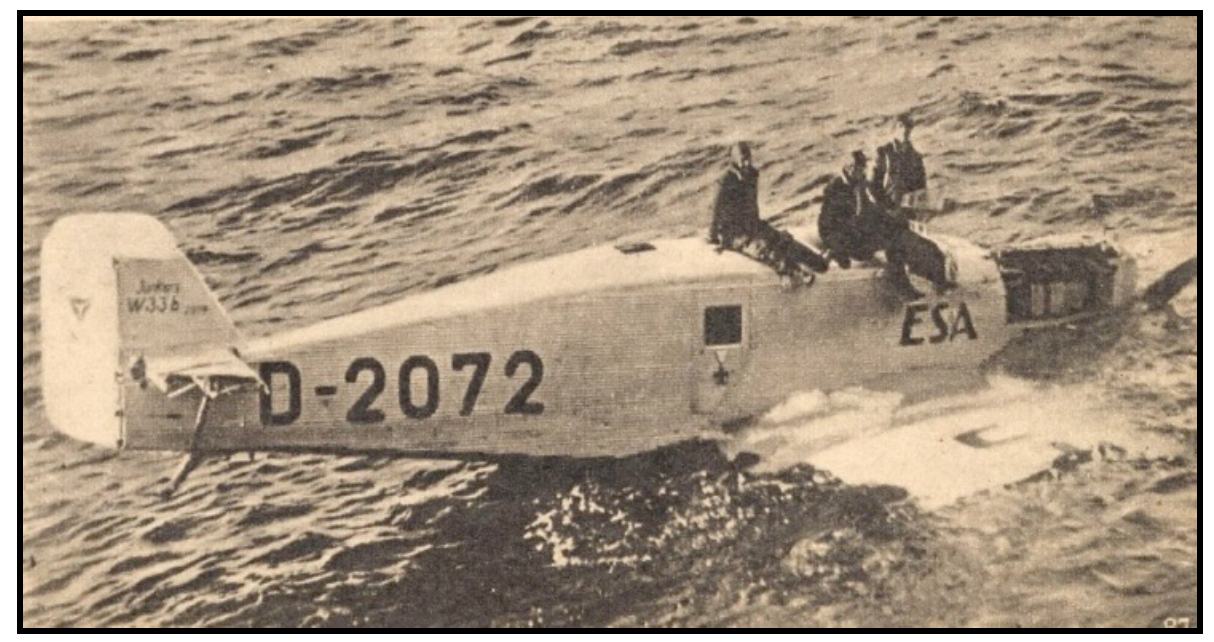

Figure 5. The Junker D-33 ESA and its three crewmembers, after ditching in the North Atlantic (magazine Der Adler March 17, 1942).

Eles são a vanguarda para a maioria dos distúrbios, nascidos na confluência das correntes frias do Labrador, da corrente quente do Golfo, ou dos intensos centros de baixa pressão da Terra Nova do Sul, passando a norte do grande Anticiclone do Atlântico, ao longo da frente polar, que vêm a assolar a Europa.

In a report of the Spanish journal $A B C$ (16 September 1931) it was stated that: "the atmospheric conditions of the Atlantic are still being those predicted by the Meteorological Service of the Navy Ministry. All seems to indicate that the aviators had deviated from the route that the services had delineated". 


\section{THE BACKGROUND TO THE CREATION OF THE NATIONAL WEATHER SERVICES}

António Gião was instructed by the Portuguese Ministry of Navy (Weather Bureau) to move to Norway to study the more "recent developments in theory and practice of dynamic meteorology" and become familiar with the "new avenues open to the weather forecast by the meteorologists of Bergen" (Gião 1927, p. 233). Gião attended the UC as a student and took an internship at the Geophysical Institute. In 1925, he moved to Strasbourg where he attended the Institute of Physics of the Globe, having obtained the qualification of 'Geographic Engineer' in 1927. In 1926 he had an article published in Nature (Gião 1926). In late 1927, while in Bergen, Gião had the opportunity to talk with Bjerknes, who was surprised that he had made such a long journey to meet him. Gião described the work done at Bergen in some detail and the theory behind 'frontology', in an article published in the Bulletin de la Société Belge d'Astronomie (Gião 1927).

Gião's activities in the following years focused chiefly on the weather. He continued his studies in Paris, in particular with the National Meteorological Services and at the Poincaré Institute. In 1929 he returned to Bergen, where he attended a free course, having developed the "mechanics of the fronts in the atmosphere"; 21 and two years later the "theory of spontaneous disruption of fluid media", which models Gião intended to apply in weather forecasting.

By the initiative of Raúl Ramalho Fernandes de Miranda (1902-1978), also a member of the IC, A Terra, a Portuguese journal on geophysics, was founded in 1931 and published at his own expense. This publication, which lasted for seven years, compiled many of the most important articles in the area. Miranda was an assistant at the Faculty of Sciences of the UC, where he obtained degrees in Geography and Geological Sciences. In the journal's first volume an article by Carvalho Brandão referred to "The particularities of weather conditions in Portugal" (Brandão 1931a), a subject on which he was deeply knowledgeable, for several years keeping a bimonthly weather chronicle in the daily newspaper Diário de noticias. In the following volume, he published an article on the 'Importance of general movements in the study of the atmosphere' (Brandão 1931b), in which he improved on the empirical nature of the French method, based on the study of the evolution and motion of cloud systems and the nuclei of pressure changes. Regarding the School of Bergen, he said that it did not yet provide a method of prediction, but merely "the acquisition of scientific knowledge about certain atmospheric phenomena from the dynamic point of view". According to Brandão, the Norwegian method was only applicable in "the regions where discontinuities of meteorological elements occur"22 (Brandão 1932, p. 9).

Referring to Gião, whom he described as being "enthused by the School of Bergen, as were all those fortunate enough to attend that temple of science", Brandão addressed the new theory that was developed from the "examination of the brilliant discoveries of $\mathrm{J}$. Bjerknes" (Brandão 1932, p. 9) and opined that the new theory of atmospheric disturbances of Gião was "more practical and more productive than that of Bjerknes". He concluded:

This method is based on the hypothesis of the reactions of general movements of the atmosphere being subject to certain conditions, established as an a priori hypothesis, without

Gião published his first works in 1929, in La mécanique différentielle des fronts et du champ isallobarique, which had forewords by Delcambre and Bjerknes. He deepened the understanding of the kinematics of fronts, having reached valuable conclusions for determining the trends of the displacement and evolution of disturbances; but, due to their differential character, he was unable to achieve useful predictions, even in the short term. 
prior study of those movements. However, it should represent a major advance in meteorological science, even if Gião's method cannot, naturally, give us a definitive solution to the problem of prediction ${ }^{23}$ (Brandão 1932, p. 10).

Brandão's article continued with an analysis of recent meteorological research, focusing on the work of the American Henry Helm Clayton (1861-1946), who was conducting research on the effect of solar variation on world weather patterns, and comparing it to the work of Gião and of Bjerknes.

In the same volume of $A$ terra there was an article by Gião (1932) in which he described his new theory and its application to weather forecasting. This was one of his first publications in Portugal. The field theory he proposed was not confined to the weather, but had applications in other fields of physics. He considered that "an experiment never has the precision and fine-tuning necessary for the [theoretical] reasoning so that in-depth explanation of phenomena normally cannot be attained" (Gião 1931, p. 12). Thus, we should distinguish between two types of phenomena or fields: the 'maintained' phenomena, the evolution of which depended only on external actions; and spontaneous phenomena, that did not have their own energy and which evolution was entirely controlled by a 'maintained' field, with which it overlapped and without which it could not exist. The atmosphere was an example of a natural system in which three 'maintained' fields overlapped: the one that resulted from gravity; another with a mechanical origin similar to the rotation of any 'astrophysical fluid'; and one of thermodynamic origin, derived from the exchanges of radiant energy between the Sun and the atmosphere (Gião 1931, p. 14).

In 1933, Miranda helped to establish the Society of Meteorology and Geophysics of Portugal (SMGP), which had Ferraz de Carvalho as Honorary Chairman. Headquartered in Coimbra, and with branches in Lisbon and Oporto, the Society published its conferences communications in its newsletter. At one of the conferences, held in Lisbon on 2 May 1933, Carvalho Brandão revealed that Gião had proposed the establishment of an Institute of Mechanics of the Atmosphere to the National Board of Education in Portugal. Unfortunately, it was found impossible to provide funds for an institution of this kind. The Board did, however, offer a scholarship to Gião to expand his research at the Prince Luís Meteorological Observatory, but he declined the offer.

In 1933, another Bergen acolyte came to Portugal to present his ice-nucleus theory, which helped to explain what causes rain to fall. The Swedish meteorologist Tor Bergeron (1891-1977) had ideas about the role of ice crystals in clouds, which were developed in his paper 'On the physics and cloud and precipitation', delivered at the Fifth General Assembly of the International Geodesy and Geophysics Union, held in Lisbon in September 1933 (Cox 2002, p. 176). Amongst the fourteen communications of the Meteorology Association at this conference, there were works by Gião on the mechanics of the atmosphere, considered to be significant by Costa Lobo (Lobo 1935). It was Costa Lobo who arranged for the assembly to be held in Lisbon and was one of its organisers.

At the Geophysical Institute of Coimbra a short-wave radio emitter was installed in 1932 to study the relations between the propagation of radio waves and meteorological phenomena. In the following years, especially after 1935, there was a period of renovation and actualisation of the meteorological equipment, started in order to accompany the evolution of meteorology: new rain sensors, anemographs and hygrometers, and a special mirror for cloud observations. Since the mechanical self-registering instruments for atmospheric pressures and air temperatures only allowed weekly register, a new daily-

Este método baseia-se porém na hipótese de serem as reacções dos movimentos gerais da atmosfera sujeitos a determinadas condições, hipótese estabelecida a priori, sem o estudo prévio daqueles movimentos; embora deva representar um grande progresso na ciência meteorológica, o método Gião não poderá, naturalmente, por esse motivo, dar-nos ainda a solução definitiva do problema da previsão. 
registering barograph and thermograph were acquired in 1936. Although the National Climate Office had been created several years earlier, in conjunction with the Prince Luís Meteorological Observatory (by then known as the Prince Luís Geophysical Institute), the cooperation of the Coimbra Geophysical Institute was only obtained in 1940. For after a visit to Coimbra of Herculano Amorim Ferreira (1895-1974), who from 1937 was also Director of the Prince Luís Geophysical Institute, the two directors managed to reach agreement about the terms of the collaboration (Santos 1995, pp. 67-68).

From the beginning of the work of the Meteorological Observatory of Coimbra, all the calculations had been done by hand, but in 1940 a mechanical calculator and an electric adding machine were purchased (Santos 1995, p. 69).

During the next few years, with the Second World War, there weren't any significant changes made to the general arrangement of the various meteorological services that were scattered among several Government departments in Portugal: the Secretariat of Civil Aviation, the Prince Luís Observatory, the Meteorological Services of the Azores (Ministry of Education), the Meteorological Services of the Navy (Ministry of Navy), the General Directorate of the Agricultural Services (Ministry of Finance) and similar offices in the ministries of the Army ${ }^{24}$ and the Colonies. The dictatorship that began in Portugal in 1926 was generally averse to major transformations. Brandão hoped to alter this situation:

His [Brandão's] great ambition was the creation of a National Institute of Meteorology, with a position reserved for me. But his project and initiatives came up against a wall of opposition, with the rivalry of fragmented offices in multiples ministries, and it was with the bitterness of not being able to accomplish anything that he died prematurely (Gião, Notas autobiográficas).

With Decree No. 35836 of 29 August 1946 the National Meteorological Services (NMS) were eventually established. Its first Director was Amorim Ferreira (1895-1974). The NMS integrated all the meteorological offices that were dispersed among different institutions and observatories, including the Geophysical Institute of the UC.

In 1945, Ferraz de Carvalho replaced Costa Lobo as President of the IC after his decease. When the NMS was created the following year, Ferraz de Carvalho asked for the termination of his position as Director of the Geophysical Institute of UC. He understood that the Geophysical Institute would maintain and strengthen the collaboration with the NMS, but without all the technical staff being transferred to this body. But his request was never granted, and nominally he stayed in charge until reaching the age limit for holding public office on 14 December 1948. However, he lost interest in the Geophysical Institute, and never entered its premises again during this period (Santos 1995, p. 70).

In his statement to the Faculty of Sciences in 1946, where he reported his thirty-two years in the direction of the Geophysical Institute, Carvalho explained the work performed there, particularly his perspective on the role of a meteorological observatory such as that which existed in Coimbra. Its first obligation was to carry out direct observations, which should be a "thorough and systematic [recording] of the meteorological elements and continuous records of the variations of many of them; then analys[is of] their correlations and the study of periodicity of the changes recorded" (Carvalho 1946, p. 12). From the accumulated results, combined studies could be made, the evolution of weather phenomena analysed. "The more extensive were the series of observations, the deeper would be the local climate studies" (Carvalho 1946, p. 12). Carvalho concluded that "an observatory alone was not able to provide short-term weather forecasts." These should be made by a group of meteorologists specialized in elaborating synoptic charts, based on short-term

The Meteorological Service of the Army had been responsible for the aerological soundings since 1932. They were performed daily at the aerological stations in Lisbon, Alverca, Sintra, Tancos and Vendas Novas. 
information from meteorological observatories and stations, connected by a network of telegraph stations. The second requirement, as always accomplished in Coimbra, was the respect for the working conditions and the publication of results at international conferences.

\section{CONCLUDING REMARKS}

Meteorological activity in Portugal during the nineteenth century was centred in the two meteorological observatories in Lisbon and Coimbra. In spite of the international contacts made by Pegado and Sousa, mainly regarding the acquisition of instruments and the establishment of observational methods and registering systems, there were seemingly no attempts to study the atmosphere and the weather to try to ascertain the laws that govern meteorological science. From the very beginning there was a determination to participate in international cooperation by sharing the data collected in the observatories or in national ships, but these efforts were intermittent. Although daily weather forecasts and storm warnings were put out by the Prince Luís Observatory from 1865 onwards, including, from 1882 to 1924 , the production of synoptic maps, a weather prediction office based on theoretical and scientific grounds only came into being with the establishment of the Navy's Meteorological Services in 1923. Carvalho Brandão sought to implement the methods of modern meteorology, with which he was well acquainted, and established international contacts with major European figures in the field such as Delcambre, Bjerknes and Shaw.

Regarding the different practices and cultures of meteorology, two different approaches are clear: the more academic one from the investigators/observers at the Coimbra observatory, mostly preoccupied with the measurement accuracy and precision of the meteorological parameters, and the more pragmatic and practical approach in maritime weather forecasting of Brandão and the Navy's Meteorological Services.

Despite the scientific knowledge and dynamism of some of the above-mentioned persons, the activity performed at each observatory was largely wasted due to the absence of a network connecting the various institutions, properly coordinated by a central structure. As we have seen, there were many such offices, each with its own director and reporting to a different ministry. The creation of this structure, through the NMS, caused some misunderstandings due to the loss of autonomy, when the meteorology required the combined effort of many institutions, acting as a cohesive network with little individual dominance.

A major difficulty was always the systemic lack of financial resources and qualified personnel, which plagued Portuguese scientific institutions more generally. A clear example was the inability to meet Gião's challenge to create an institute devoted to the study of the atmosphere, thereby wasting the contribution of a significant Portuguese researcher who spent much of his career in the service of European universities and institutes. Gião corresponded with Albert Einstein in 1946 on the application of a new mathematical concept in cosmology and particle physics. Only in 1960 did he start to teach in Portugal, at the invitation of the Mathematics School of the Faculty of Sciences at Lisbon University.

Despite its ambitious objectives and the involvement of major national figures, the creation of the Society of Meteorology and Geophysics of Portugal in Coimbra did not gather the required governmental support to evolve into something permanent, being almost extinguished after only a few years of existence.

For these reasons, the history of meteorology in Portugal in the first half of the twentieth century had a chequered course. It had some isolated successes but also periods of confusion and stagnation. The advances were generally due to the individual merit of some personalities who, having realised the importance of this new area of science, sought to achieve results similar to those obtained in the more developed countries. However, the shortage of funds, especially during the so-called First Republic (1910-1926), and also the 
shortage of technically competent and well-motivated personnel, hindered progress. After 1960, José Pinto Peixoto (1922-1996), a physics professor at the University of Lisbon, was one of the most important scientists for the NMS development. At the Massachusetts Institute of Technology (MIT) in Boston, where he wrote his PhD in the sixties, he had the opportunity to work with renowned physicists such as Victor Starr, Edward Lorenz and Abraham Oort, who were responsible for the first systematic studies of the global circulation of the atmosphere. MIT's meteorology program contributed to the transformation of meteorology into a sophisticated scientific discipline based on physics and mathematics (see Harper 2008).

International pressure for the advancement of meteorology in Portugal was always present, especially after the observations gathered there and in its possessions in the Atlantic archipelagos (Madeira and Azores) became essential to the development of global weather forecasting. The North Atlantic Anticyclone is today sometimes called the Azores Anticyclone, at least in Europe. ${ }^{25}$

\section{ACKNOWLEDGMENTS}

We are indebted to the Portuguese Foundation for Science and Technology (FCT) for the financial support that made possible the cataloguing of the library and archive of the Instituto de Coimbra at the General Library of the University of Coimbra, for a scholarship awarded to the first author, and also for the project 'History of Science at the University of Coimbra (1547-1933)' (HC/0119/2009). We are also grateful to José Carlos Tiago de Oliveira, Maria do Rosário Pereira and Catarina Pinto for their careful reading of the manuscript and useful suggestions.

\section{ARCHIVES}

Gião, António. 'Notas autobiográficas para esclarecer as razões do meu fracasso' (undated manuscript in French, transcribed in 2008 by Stéphane Roualt and translated into Portuguese by José Carlos Tiago de Oliveira).

Santos, Vitorino Gomes de Seiça e. 1995. 'O Instituto Geofísico da Universidade de Coimbra (Bosquejo histórico)'. Coimbra (unpublished historical report of the Geophysical Institute of Coimbra).

\section{REFERENCES}

Abreu, J. Maria de. 1857. Observações meteorológicas em Madrid. Resumen de los trabajos meteorológicos correspondientes al año 1854 , de D. Manuel Rico y Sinobas. O Instituto: journal scientifico e litterario 6: 174-175.

Aires, Bernardo. 1892. A circulação atmosférica e a previsão do tempo. Coimbra: Imprensa da Universidade.

Annaes do Observatorio do Infante D. Luiz em Lisboa. Volume Primeiro 1856 a 1863. 1864. Lisboa: Imprensa Nacional.

Anderson, Katherine. 2005. Predicting the Weather: Victorians and the Science of Meteorology. Chicago: The University of Chicago Press.

Bjerknes, J. 1928. Les bases scientifiques et techniques de la prévision du temps et le rôle du Portugal à ce rapport. O Instituto: journal scientifico e litterario 75: 90-111.

Boletins da Sociedade de Meteorologia e Geofisica de Portugal. 1934. Coimbra: Tipografia Bizarro.

Branco, Hugo C. L. Castelo. 1935. Nota a propósito de uma catalogação especial dos tempos, podendo ser considerada como auxiliar na previsão do tempo. A Terra: revista Portuguesa de geofísica 21: $1-7$. 


\section{METEOROLOGICAL OBSERVATIONS IN COIMBRA}

Brandão, A. Carvalho. 1925. Os modernos métodos de previsão do tempo em Portugal. Memória apresentada no Congresso de Coimbra de 1925. Lisboa.

Brandão, A. Carvalho. 1927. Condições para o progresso da meteorologia Ibérica: comunicação presente ao Congresso de Cádiz em 1927. Lisboa: Imprensa da Armada.

Brandão, A. Carvalho. 1931a. Particularidades das situações meteorológicas de Portugal. A Terra: revista Portuguesa de geofísica 1:3-6.

Brandão, A. Carvalho. 1931b. Importância dos Movimentos Gerais no estudo da atmosfera. A Terra: revista Portuguesa de geofísica 2: 1-8.

Brandão, A. Carvalho. 1933. Para que se fundou a Sociedade de Meteorologia e Geofísica de Portugal. Boletim da Sociedade de Meteorologia e Geofísica de Portugal.

Burton, Jim. 1986. Robert FitzRoy and the early history of the Meteorological Office. The British Journal for the History of Science 19: 147-176.

Carvalho, Anselmo Ferraz de. 1922. Clima de Coimbra [The Climate of Coimbra] Resumo das Observações feitas no Observatório Meteorológico da Universidade de Coimbra desde 1866. Lisboa: Imprensa Nacional.

Carvalho, Anselmo Ferraz de. 1946. Trinta e dois anos na direcção do Instituto Geofísico de Coimbra: breve relatório apresentado à Faculdade de Ciências. Coimbra: Atlântida.

Carvalho, Joaquim Augusto Simões de. 1871. Meteorologia: saraiva. O Instituto: journal scientifico e litterario 15: 132-135.

Carvalho, Joaquim Augusto Simões de. 1872. Memória histórica da Faculdade de Philosophia. Coimbra: Imprensa da Universidade.

Casati, Stefano and Ciardi, Marco. 1998. Meteorology: disciplinary history. Sciences of the Earth: An Encyclopedia of Events, People and Phenomena, edited by Gregory A. Good, Vol. 2, 564-571. New York: Garland Publishing.

Castro, Egas e, 1909. Geodynamica tellurica. Cálculo provisório do hipocentro do sismo de 23 de Abril de 1909. O Instituto: journal scientifico e litterario 56: 586-599.

Cox, John D. 2002. Storm Watchers: The Turbulent History of Weather Prediction from Franklin's Kyte to El Niño. New Jersey: John Wiley and Sons, Inc.

Chapman, Sydney, 1937. A maré atmosférica lunar em Coimbra. O Instituto: journal scientifico e litterario 91: 445-451.

Davis, John L. 1984. Weather forecasting and the development of meteorological theory at the Paris Observatory, 1853-1878. Annals of Science 41: 359-382.

Dr Bjerknes. Diário de Notícias 8 May 1927: 9.

Eliassen, Arnt. 1995. Jacob Aall Bonnevie Bjerknes 1897-1975: A Biographical Memoir. Washington DC: National Academies Press.

Ferreira, H. Amorim. 1940. O observatório do Infante D. Luiz: memória apresentada pelo director do Observatório. Congresso de História da Actividade Científica Portuguesa. Lisboa.

Fleming, James Rodger. 1998. Meteorological services, national and regional. In: Sciences of the Earth: An Encyclopedia of Events, People and Phenomena, edited by Gregory A. Good, Vol. 2, 558-561. New York and London: Garland Publishing.

Friedman, Robert Marc. 1989. Appropriating the Weather: Vilhelm Bjerknes and the Construction of a Modern Meteorology. Ithaca: Cornwell University Press.

Gião, António. 1926. Cirrus at a lower level than alto-cumulus. Nature 118: 49-49.

Gião, António. 1927-1928. La meteorologie à Bergen, aujourd'hui et demain. Ciel e tierre: Bulletin de la Société belge d'astronomie 43: 233-238, 44: 9-23, 45-53, 93-106, 147-153, 190-202, 253255.

Gião, António. 1929. La mechanique différentielle des fronts et du champ isallobarique. Paris: Memorial de l'Office National Météorologique de France.

Gião, António. 1931-1932. A teoria dos campos e a previsão do tempo. A Terra: revista Portuguesa de geofísica 2: 12-17, 3: 4-12, 4: 5-12, 5: 1-5.

Goulão [S. G.]. 1854a. Observações meteorológicas. O Instituto: journal scientifico e litterario 2: 260-262.

Goulão, Sanches [S. G.] 1854b. Meteorologia. O Instituto: journal scientifico e litterario 3: 166-168, 221-222.

Harper, Kristine C. 2008. Weather by the Numbers: The Genesis of Modern Meteorology. Cambridge: Massachusets Institute of Technology. 


\section{ANTÓNIO JOSÉ LEONARDO, DÉCIO MARTINS and CARLOS FIOLHAIS}

Lartigue, Jean. 1854. Física do globo: exposição do sistema dos ventos. O Instituto: journal scientifico e litterario 3: 85-87.

Leonardo, A. J. F., Martins, D. R. and Fiolhais, C. 2009a. O Instituto de Coimbra: breve história de uma academia científica, literária e artística. In: Tesouros da biblioteca geral da Universidade de Coimbra (coordenação de A. E. Maia Amaral), 115-125. Coimbra: Imprensa da Universidade.

Leonardo, A. J. F., Martins, D. R. and Fiolhais, C. 2009b. A telegrafia eléctrica nas páginas de "O Instituto", revista da Academia de Coimbra. Revista Brasileira de Ensino de Física 31: 2601.1-2601.13.

Leonardo, A. J. F., Martins, D. R. and Fiolhais, C. 2011. Costa Lobo and the study of the sun in Coimbra in the first half of the twentieth century. Journal of Astronomical History and Heritage (preprint).

Lobo, F. M. da Costa. 1935, Relatório da quinta assembleia geral da União Geodésica e Geofísica Internacional, reunida em Lisboa se 17 a 25 de Setembro de 1933, exposto na Sociedade de Geografia de Lisboa, pelo Presidente da Secção Nacional, F. M. da Costa Lobo. Revista da Faculdade de Ciências [da] Universidade de Coimbra 5: 105-128.

Lopes, Adriano de Jesus, 1893. Observatório meteorológico e magnético da Universidade de Coimbra. O Instituto: journal scientifico e litterario 40: 201-209.

Malaquias, I., Gomes, E. V. and Martins, D. R. 2005. The genesis of the geomagnetic observatories in Portugal. Earth Sciences History 24: 113-126.

Mata, José Nunes da. 1903. Elementos de meteorologia náutica. Rápido estudo da origem e constituição da Terra: correntes marítimas e previsão de tempo, 253-264. Lisboa: Libraria Ferin.

Middleton, W. E. Knowles. 1969. Invention of the Meteorological Instruments. Baltimore: The Johns Hopkins University Press.

Monteiro, Ana. 2001. O reconhecimento oficial da climatologia em Portugal (1850-1900). História: revista da Faculdade de Letras, Series 2. 3: 167-174.

Morna, Álvaro de Freitas. 1934. A preparação meteorológica da travessia do Atlântico pelo avião "Esa". A Terra: revista portuguesa de geofisica 3: 1-11.

Morna, Álvaro de Freitas. 1934-1935. Meteorologia. A Terra: revista portuguesa de geofisica 16: 2732, 17: 29-30, 18: 19-31, 19: 16-27, 20: 20-25.

Nunes, Maria de Fátima. 1988, O universo estatístico de Marino Miguel Franzini (1800-1860). In: $O$ Liberalismo Português: Ideários e Ciências. Lisboa: Instituto Nacional de Investigação Científica.

Observações meteorológicas (Gabinete de Física) (1852-1854). O Instituto: journal scientifico e litterario $2: 255,260,285 ; 3: 12,36,92,120,148,224,252,268 ; 4: 64,76,136,160,172,178$, 192, 204, 216, 228, 240, 252, 264, 276.

Observações meteorológicas (1866-1890). Observatório Meteorológico e Magnético da Universidade de Coimbra 1891. Coimbra: Imprensa da Universidade.

Observações meteorológicas e magnéticas. 1891-1908. Observatório Meteorológico e Magnético da Universidade de Coimbra. Coimbra: Imprensa da Universidade.

Observações meteorológicas, magnéticas e sísmicas. 1909-1920. Instituto Geofísico da Universidade de Coimbra. Coimbra: Imprensa da Universidade.

Peixoto, José Pinto and Ferreira, José F. V. G. 1986. As ciências geofísicas em Portugal. História e desenvolvimento da ciência em Portugal. Lisboa: Academia de Ciências de Lisboa.

Projecto de organização dos serviços meteorológicos. Relatório. [1936]. A Terra: revista Portuguesa de geofisica 22: 2-9.

Raposo, Pedro M. P. 2004. Campos Rodrigues: o homem do mar, o engenheiro hidrógrafo, o astrónomo. In: Jornadas do mar 2004: O mar: um oceano de oportunidades, 549-556. Almada: Escola Naval da Marinha Portuguesa.

Saturnino, Óscar. 1934. Interesse social da cosmofísica. Boletim da Sociedade de Meteorologia e Geofisica de Portugal 1: 20-21.

Simões, A. Filipe. 1875. Notícia do posto meteorológico de Évora. O Instituto: journal scientifico e litterario 20: 78-83.

Sousa, Jacinto António de. 1861. Relatório da visita aos estabelecimentos scientificos de Madrid, Paris, Bruxellas, Londres, Greenwich e Kew. O Instituto: secção official. Legislação e documentos relativos à instrução pública, 117-150. 


\section{METEOROLOGICAL OBSERVATIONS IN COIMBRA}

Sousa, J. António. 1870. Prefácio. Resumo das observações meteorológicas feitas no Observatório meteorológico e magnético da Universidade de Coimbra de 1864 a 1866. Observatório meteorológico e magnético da Universidade de Coimbra 3-7. Coimbra: Imprensa da Universidade.

Tavares, Conceição, 2009. Albert I do Mónaco, Afonso Chaves e a Meteorologia nos Açores. Ponta Delgada: Sociedade Afonso Chaves e Centro Interuniversitário de História das Ciências e da Tecnologia.

Trabalhos do Observatório Meteorológico do Infante D. Luiz na Escola Polythecnica, 1. ${ }^{\circ}$ anno (18541855). 1856. Lisboa: Imprensa Nacional.

Trabalhos scientíficos anunciados e na quási totalidade apresentados ao Congresso. 1925. O Instituto: journal scientifico e litterario 71: 624-625.

'Um meteorologista: ouvindo o Dr. J. Bjerknes acerca da nova estação dos Açores', Diário de Notícias 13 May 1927: 1.

Vasconcelos, Frazão de. 1960. António de Najera, matemático do século XVII, era português ou castelhano? Boletim geral do ultramar 36: 271-274.

Vasconcelos, Matias de Carvalho. 1856. Observações meteorológicas na Universidade de Coimbra. $O$ Instituto: journal scientifico e litterario 5: 119-120.

Vasconcelos, Matias de Carvalho. 1858. Relatórios dirigidos à Faculdade de Filosofia da Universidade de Coimbra pelo seu vogal em comissão fora do reino. O Instituto: journal scientifico e litterario 7: 134-136. 